\title{
Analytical Philosophy to Philosophical Analysis Arthur C. Danto's Analytical Approach to the Formation of Aesthetic Thought
}

\author{
Pengju Zhang ${ }^{1, *}$ Hai Liang ${ }^{1}$
}

${ }^{1}$ Faculty of Humanities and Social Sciences of DUT, Dalian University of Technology, Dalian, Liaoning 116024, China *Corresponding author. Email: 873417108@qq.com

\begin{abstract}
Arthur C. Danto's analytical aesthetics occupies an important theoretical position in the history of analytical aesthetics. If the "Artworld" theory is a useful attempt by Danto to use analytical philosophical methods to analyze works of art; then "The Transfiguration of the Commonplace" can be said to be the successful application of Danto's theory of analytical aesthetics to explain and criticize art practice activities, marking the formal formation of Danto's analytical aesthetics; the publication of "The End of Art" marks the dissolution of its analytical aesthetic thought and the return of its artistic theory to philosophy. It can be seen from the "Artworld" through "The Transfiguration of the Commonplace" to "The End of Art" that Danto's analytical aesthetics development begins with philosophy and ends with the theoretical approach of philosophy; the article has certain value for understanding the significance of contemporary art.
\end{abstract}

\section{Keywords: Arthur C. Danto, analytical aesthetics, theoretical approach}

\section{INTRODUCTION}

Arthur C. Danto is a world-renowned contemporary analytical aesthetician and art critic. Since the 1980s, his "The End of Art" has exerted a great influence in the international aesthetics and art theory circles, and is still a topic of great interest in the academic circle. In the contemporary European and American analytical philosophical circle, Danto has a very high status. Some scholars have listed Danto as the "most outstanding philosopher of the contemporary age" along with pure analytical philosophers such as Quinn, Davidson and Putnam. In his article "The Decline and Recovery of Analytical Aesthetics", Margolis believes that Beardsley, Goodman, Danto and himself are the four most influential masters in the history of analytical aesthetics[1]. From this, it can be seen that Danto's important position in analytical aesthetics.

Although, in recent years, with the popularity of environmental aesthetics and life aesthetics in Chinese aesthetic circles, coupled with the long-term influence of continental philosophy and aesthetics in mainland China, analytical aesthetics in Chinese aesthetic circles has not occupied the mainstream position. But for a long time, Danto's aesthetic thought has been widely concerned by Chinese scholars. Liu Yuedi's "History of Analytical Aesthetics", published in 2009, lists Danto's analytical aesthetics in a single chapter and gives a detailed introduction. In addition, Prof. Peng Feng of
Peking University, Prof. Gao Jianping of the Academy of Social Sciences and other experts in the Chinese aesthetic circle have conducted in-depth research on Danto's analytical aesthetics. All these provide an important theoretical basis for further organizing Danto's analytical aesthetics. In the following, the author tries to sort out the analytical aesthetics in the order of Danto's related concepts, in order to have a macroscopic understanding of the internal logical evolution of Danto's analytical aesthetics.

\section{II. "ARTWORLD": FROM ANALYTICAL} PHILOSOPHY TO EVOLUTION OF ARTISTIC ANALYSIS

At the 61st Annual Meeting of the Eastern Conference of the American Philosophical Society in 1964, Danto publicly announced his "Artworld" article. It was in this article that Danto presented his famous "Artworld" theory. This theory has an important role in the history of contemporary analytical aesthetics, which can also be seen as a sign of Danto's shift from the philosophical field to aesthetics.

Danto's "Artworld" theory begins with the traditional European concept of art, namely the Imitation Theory (IT). In Danto's view, the reason imitation theory can continue to exist in art history for so long is because it can effectively explain the causal relationship between works of art and a large number of 
phenomena of art evaluation. Danto believes that according to imitation theory, from Socrates to Hamlet in Shakespeare's hands, art is seen as a mirror of nature. But the difference between them is that Socrates believes that the representations shown in the mirror are only accurate but useless replicas. Therefore, such representations have no cognitive value. Shakespeare thinks that "the mirror shows us ourselves". By comparison, it can be found that the same is the theory of imitation. Socrates pays more attention to the imitation of the external nature, while Shakespeare pays more attention to the imitation of the inner world. From this the logical tension inherent in Imitation Theory can be discovered. It is in this situation that Danto pointed out the inherent contradiction that imitation theory cannot solve. "If mirror image $\mathrm{O}$ is imitation of $\mathrm{O}$, then art is imitation, mirror image is art, but in fact mirror image is not art..."[2] However, the invention of photographic art had a huge impact on imitation theory. The reality that abstract art once occupied the mainstream of the Artworld could not be effectively explained through imitation theory, which caused a fatal blow to imitation theory.

It is precisely under the circumstances that traditional art imitation theories have been hit by practice one after another, Danto borrowed the research methods of analytical philosophy and began to advocate the separation of artistic objects from non-art works through "linguistic analysis". Danto believes that, like the construction of reality by language, the role of theory in reality has also been neglected in the context of the past. This is not only because art is indistinguishable from other objects, but also that "art theory" does not play a big role in determining "what is art". This is because people do not realize the need for theoretical reflection between "what is art" and "what is non-art", but take it for granted that the "something is art" determined in a specific field is established by people and does not need to be proved by theory. Danto believes that to determine something as art requires the use of art recognition, and it is in this situation that Danto analyzes the predicate is. Danto once assumed that he was accompanying others in visiting the exhibition. He pointed to a spot in the previous painting and said to his friend, the "is" in "That white spot is Icarus" is not the same as the "is" of describing the identity of Venus as a morning star as being hot and the "is" of indicating the attribute that describes Venus.[3] The latter "is" is in the context of everyday life, while the former "is" is only a judgment and description of works of art, and is limited to the Artworld. In other words, in Danto's view, something must pass the judgment and description of this special "is" predicate in the Artworld in order to indicate the identity of its artwork, that is, the judgment that an artwork is an artwork comes from the judgment of the external Artworld, not from the appeal to the artwork's own attributes. Under this circumstance, the role of "art theory" becomes clear. In Danto's view, "art theory" can not only help people distinguish between art and non-art, but also make art possible with its own power.

After "IT", Danto put forward the concept of "Reality Theory" (RT). What is Danto's "Reality Theory"? Liu Yuedi translated it into "authenticity theory", and believed that Danto's RT theory was directly triggered by Frye's "The purpose of art is 'not in illusion but in authenticity"'[4]. The emergence of RT has put the art viewed according to IT back into a new perspective. And Danto's modern art was demonstrated as an example. In Danto's view, it was through RT that postmodern art, pop art, and brutalism, which were previously unexplainable through IT, can be proved. A philosophical question is involved here, that is, why ordinary people regard these artworks as "real objects", while others can think it "authenticity" according to RT. Danto brought this question to the ontological level, "Why do ordinary people as recipients have such misunderstandings? Why do artists as creators avoid such misunderstandings? Can someone mistake the (previous) 'reality' as (the latter) 'reality'? In a nutshell, what is it that makes it an art?"[5] Danto took Rauschenberg's bed as an example to discuss this issue. He said, "The object is not just a bed, but a complex object that happened to be sprinkled with some paint: 'Paint bed'... When the real thing $\mathrm{R}$ is part of the artwork $\mathrm{A}$ and can be separated from $\mathrm{A}$ at the same time, and is only regarded as R, not every part of A is a part of R. In this way, the mistake made so far is to mistake A as a part of $\mathrm{R}$, although it is not correct to say that A is R and the artwork is a bed."[6] Danto's general meaning is roughly assuming that the bed as a true meaning is part of the bed in the sense of Rauschenberg's artwork, and if the paint on the bed in the sense of Rauschenberg's artwork is removed, the bed as a work of art becomes a real bed, which means that not every part of the work of art forms part of the ready-made object. And ordinary people have a misunderstanding when they look at artworks as part of ready-made objects. This also shows that it is wrong to deduce that the artwork is equal to the ready-made object itself, and there is no equal sign between the artwork and the bed of the ready-made object. It is in this situation that Danto introduced the two important conditions of "Artworld" and "art theory", that is to say, in Danto's view, the work of art must satisfy these two necessary conditions, In order to make "the art's 'is"' into a philosophical "is".

All in all, in Danto's view, to confirm that an item belongs to a work of art is to put it into a "historical atmosphere" and "art theory" to understand together. The former is a historical investigation, and the latter is a theoretical Investigate. In other words, Danto believed that it is the art theory that distinguishes ready-made objects from works of art. It is the art theory that 
confirms that works of art are works of art. It is the art theory that brings the real thing $\mathrm{R}$ into art $\mathrm{A}$. This can also be seen as the theoretical attempt of Danto's smooth transition from philosophical analysis to aesthetic analysis. The "Artworld" theory also marks Danto's formal entry into the field of analytical aesthetics and the use of analytical philosophy to study beauty and art.

However, it is worth noting that although Danto's "Artworld" theory has made an important theoretical contribution to the distinction between art and non-art. However, there is a hidden danger in the theory of Danto that completely separates art from life.[7] That is to say, according to Danto's "Artworld" theory, art and life are not equal, and there is a drawback that art overrides life. In recent years, the aestheticization of daily life has developed rapidly. With the growing aesthetics of life, they advocate that everyone is an artist. Obviously, Danto's "Artworld" theory has the denial that the rationality of life's penetration into art has been unable to adapt to the essence of aesthetic generalization, which is also a theoretical limitation that his "Artworld" theory has to face.

\section{III. "THE TRANSFIGURATION OF THE COMMONPLACE": FROM ARTISTIC ANALYSIS TO THE FORMATION OF ANALYTICAL AESTHETICS}

After Danto proposed the "Artworld" theory, he also proposed the "The Transfiguration of the Commonplace" to further explain his artistic ontology. This theory came from the famous artist Duchamp's urinal named "Fountain" who participated in the exhibition in 1917 and became famous in one fell swoop. This raises the question, why are the urinals put in the store unusual, and the urinals that Duchamp took at the exhibition became works of art? Similarly, in 1964, the famous American pop artist Andy Warhol copied the soap packaging box with the word "Brillo" bought from the supermarket with wooden products, single or multiple superimposed, and get directly to the museum for exhibitions, which has also achieved great success. This aroused the reflection of the Dantos. Why did it seem that two completely similar "feeling indistinguishable" objects, one became a work of art, and the other was not?

From Danto's point of view, it is clear that people cannot distinguish this problem from the surface of the naked eye. People cannot distinguish the difference between ordinary objects and works of art by sight alone. Inspired by Wittgenstein and his successor's "action" theory, Danto changed the "parody theory" since the long Plato, and gave art a minimal definition "only when an object is under the interpretation I can a thing $\mathrm{O}$ be a work of art, that is: $\mathrm{I}(\mathrm{O})=\mathrm{W} "[8]$. It can be seen from this definition that Danto expressed the two necessary conditions for becoming a work of art. This object must be about something; it expresses a certain meaning. If something satisfies both of these conditions, it can be shaped into a work of art. Therefore, in Danto's view, the essential provisions of art as art are: "relevance" and "meaning". And that these two conditions have a time-space property, not only can be applied to all works of art in art history, but also can be adapted to works of art in various parts of the world. It is through this simple definition of art that Danto tried to respond to the impact of the development of art practice since "Bullley Box" on art theory. If the "Artworld" theory can be regarded as a sign of Danto's turn from analytical philosophy to artistic analysis, then the idea of "The Transfiguration of the Commonplace" can be seen as a sign of the formal formation of Danto's analytical aesthetics.

However, it is worth noting that Danto's definition of the ontology of art was published in "The Transfiguration of the Commonplace", which basically did not change. He even thought that until 2500, "relevance" and "meaning" would still be two necessary conditions for art to be art. From Danto's point of view, his definition of art no matter when or where art is created, it is applicable to every piece of art. This definition of art not only has a span in time, but also has a transcendence in space. Therefore, there are two loopholes in analyzing Danto's definition of art from the perspective of art ontology. On the one hand, this definition ignores the test of time. As it known to all, truth is relative, any truth is conditional, and there is no absolute truth. Similarly, Danto's definition of art will never be set in stone. As mentioned above, "Imitation Theory" of art has long occupied an important position in the history of art. However, with the success of postImpressionism, especially pop art represented by "Bullley Box" and modern art such as Fauvism and Dadaism, Plato's "Imitation Theory" no doubt can no longer use the needs of artistic practice. On the other hand, Danto's art definition has the defect of neglecting the difference between Eastern and Western art to some extent. If viewed from a cross-cultural perspective, when the necessary conditions of these two arts meet Danto's statement that art is always related to something and presents a certain meaning, it can be thought that this concept is conducive to understanding the difference between all art and non-art, including Eastern art. However, it can be seen from art practice and art history that the development of Western art and non-Western art has been inconsistent for a long time, and it can be said that there is a big difference in a certain sense. For example, taking Chinese art as an example, there is no art in Chinese history. China has only artistry. Obviously, "art" is a foreign product. Can this foreign product meet the needs of Chinese art practice and meet the Chinese environment? The author thinks this is a question worthy of reflections in the artistic definition of Danto. 


\section{IV. "THE END OF ART": FROM ANALYTICAL AESTHETICS TO PHILOSOPHY'S DEPRIVATION OF ART}

In 1984, Danto published two articles "Deprivation of Philosophy to Art" and "The End of Art", especially the publication of "The End of Art" which caused an uproar in the academic circle. In Liu Yuedi's opinion, "The End of Art" is undoubtedly the "most comprehensive deprivation" of the rights of art.[9] In recent years, as mentioned above, with the continuous development of contemporary art practice, the line between art and daily life has become increasingly blurred. The call for "art death", "end of art history", and the appeal of "everyone is an artist" appealed to by life aesthetics are getting higher and higher in European and American aesthetics and the Artworld, and have become increasingly important and widespread in mainland China. However, in fact, the initiator of "The End of Art" theory was not Danto himself, but was first proposed by Hegel in the aesthetics class at the University of Berlin in 1828. Hegel's "The End of Art" was proposed because, on the one hand, it is caused by the overall artistic and cultural conditions of the civil society era in which Hegel is located; on the other hand, according to the deduction of Hegel's ideological system, "spirit" must be freed from the shackles of emotion to surpass the truth, that is to say, art must be gradually abandoned to integrate into the embrace of religion.[10] This can also be regarded as another important reason put forward by Hegel's "The End of Art". From the previous aspect, classical art, which represents the glorious stage of art, is long gone. "Art, is no longer able to achieve the satisfaction of the spiritual needs that the past eras and past nations are looking for in art, and only in art..."[11] In Hegel's view, the civil era in which he is located has been unable to fully realize the functions of art, and it is not surprising that art is coming to an end. Viewed from the latter aspect, in Hegel's view, art should liberate people's spirit from the content and form of the limited world to show absolute truth. Hegel believes that the highest function of art is outdated for the people in his time, and has already been transferred to people's ideas. Art as the lower stage of the absolute spirit must inevitably develop into the higher stage of religion, in order to conform to the three-stage theory that he constructed for the absolute spirit from art to religion, and finally to philosophy. In short, it is Hegel's dissatisfaction with the reality of his own civil society and the inevitable logical evolution of his absolute spiritual development that led Hegel to lay the groundwork for Danto's "The End of Art".

Unlike Hegel's "The End of Art", Danto believes that the end of his art does not mean the death of art, not that art has developed to no longer need art, but that it is mainly based on the "historical" proposition. So what does Danto's "End of Art" mean? What position does the "The End of Art" occupy in his theoretical system? What impact did "The End of Art" he put forward have on the theoretical construction of contemporary art and aesthetics? How does Danto respond to his theory of "The End of Art" in the face of the constant practice of art in today's era? How should people view his thought-provoking theory? These are the insurmountable problems of accurately grasping Danto's analytical aesthetics.

The End of Art of Danto's art is directly rooted in the face of the development of contemporary art practice, but traditional art definitions such as imitation and aestheticism cannot explain why art is art.[12] Liu Yuedi believes that Danto's "The End of Art" generally contains three meanings. First, the development of art has completed its theoretical planning, and within the predictable time, art will no longer have a predictable breakthrough. This is precisely why, as mentioned above, the "relevance" and "meaning" he mentioned for art will not be outdated until 2500. Second, art has entered a stage of no evolution. Third, art evolves according to established plans and will not become anything else. [13] From this definition, it can be seen that "The End of Art" that Danto said is not the "art death" in the usual sense, just as he once wrote to argue for himself in "After the End of Art - The Boundary of Contemporary Art and History": "Neither of us (referring to Hans Belting) is talking about the death of art, although one of my articles happened to be included in a collection called 'The Death of Art' and was used as the theme article. The title of the book is not from my article, because I am writing a narrative that has been objectively implemented in the history of art. It seems to me that this narrative has come to an end. A story is over. My point of view is not that there is no more art, this is the meaning of 'death'; my point of view is that no matter what kind of art it may be, it can be created without the benefit of a reliable narrative;... What ends is the narrative, not the theme of the narrative."[14]

Since, in Danto's view, what he said of "The End of Art" does not mean the death of art, but the end of a grand narrative model. So, what is art after the end of art that Danto believes? On this issue, clues can be found in Danto's "After the End of Art". According to Danto, the art after the end of art is the art after the philosophical reflection. He said that wherever art includes everything authorized as art, there will be a question "Why am I a work of art?" "When philosophical truth (once discovered) must be consistent with art in every possible way, what Greenberg did was use art philosophical truth to identify certain abstract artistic styles"[15]. That is to say, in Danto's view, the art after the end will turn to the field of philosophy, which can be seen in a sense that Danto has returned to Hegel more than a hundred years ago. Danto himself believed that he, like Hegel, 
was also predicting the future of art in history, and felt complacent that he can be said to coincide with Hegel

As for the art after the end of art, it is the question of how Danto calls "post-historical art". As Danto said, the end of art does not mean the death of art. Art practice will continue to move forward, and will continue to move forward in the art world without any grand narrative structure. The author believes that after the history of Danto's grand narrative of art ends, art will develop towards diversification and anti-ontology. It is against this background that the natural environment can become an aesthetic object, and the daily life people live in can become a carrier of art. It is precisely because of the increasingly blurring or even disappearing of the boundary between the living world and art that the slogans of "Everyone is an artist", "Aestheticization of daily life" and "Lifelization of aesthetics" may appear. To borrow Danto's own words, "In a sense, when the story comes to an end, life really begins."[16] In recent years, the environmental aesthetics and life aesthetics discussed in art theory and aesthetics are its characteristics. [17]

Of course, Danto's "The End of Art" has attracted continuous attention in the theoretical world and made it famous throughout the world. However, while "The End of Art" has given Danto a great reputation, it has also set a target for the academic circle to criticize Danto. For example, some scholars believe that Danto's "The End of Art" is based on the analysis of painting art. There is tension between his theoretical thinking and the practice of artistic practice. This is also an important aspect that Danto's "The End of Art" believes that art will move toward philosophy, which is widely criticized by Chinese and Western scholars.

\section{CONCLUSION}

In short, the formation of Arthur Danto's analytical aesthetics experienced a theoretical process that began with analytical philosophy and ended up with philosophical analysis. The introduction of the concept of "Artworld" marks that Danto's research interest has shifted from analytical philosophy to analytical aesthetics, while "The Transfiguration of the Commonplace" marks the final formation of Danto's analytical aesthetics. The suggestion of "The End of Art" means that Danto, who was born of analytical philosophy, could not extricate himself because of his way of thinking in analytical philosophy, which eventually led to the theoretical collapse of his aesthetic thought. This article has certain enlightenment for understanding the significance of contemporary art.

\section{References}

[1] Richard Shusterman ed., Analytic Aesthetics, p.161-189.

[2] Arthur C. Danto, "The Artworld" [J]. The Journal of Philosophy, p.571.

[3] Arthur C. Danto ,"The Artworld" [J]. The Journal of Philosophy, p.576.

[4] Liu Yuedi, The History of Analytic Aesthetics [M]. Peking University Press, 2009, p206. (in Chinese)

[5] Liu Yuedi, The History of Analytic Aesthetics [M]. Peking University Press, 2009, p208. (in Chinese)

[6] Arthur C. Danto, "The Artworld" [J]. The Journal of Philosophy, p.576.

[7] Sun Yanqiu, A New Possibility of Definition of Art - Ideas of Arthur Danto about "Artworld" [J]. Academic Journal Graduate School Chinese Academy of Social Sciences, 2009, 02, p106111. (in Chinese)

[8] Arthur C. Danto, The Transfiguration of the Commonplace [M] Cambridge: Harvard University, p5.

[9] Liu Yuedi, The History of Analytic Aesthetics [M]. Peking University Press, 2009, p220. (in Chinese)

[10] Liu Yuedi, On the Philosophical Disenfranchisement of Contemporary Art [J]. Philosophical Researches, 2006, 02, p78. (in Chinese)

[11] Hegel, Aesthetics: Volume 1 [M]. Zhu Guangqian, trans. Beijing, The Commercial Press, 1979: p14. (in Chinese)

[12] Zhang Bing, The Philosophical Standpoint of Danto's Artistic View [J]. Journal of Lanzhou, 2008, 04, p18. (in Chinese)

[13] Liu Yuedi, The History of Analytic Aesthetics [M]. Peking University Press, 2009, p219-220. (in Chinese)

[14] Danto, After the End of Art - The Boundary of Contemporary Art and History $[\mathrm{J}]$. Wang Chunchen, trans. Jiangsu People's Publishing House, 2007, p5. (in Chinese)

[15] Danto, After the End of Art - The Boundary of Contemporary Art and History $[\mathrm{J}]$. Wang Chunchen, trans. Jiangsu People's Publishing House, 2007, p17-18. (in Chinese)

[16] Danto, After the End of Art - The Boundary of Contemporary Art and History [J]. Wang Chunchen, trans. Jiangsu People's Publishing House, 2007, p6. (in Chinese)

[17] Andrew Light and Jonathan M.Smith(eds), The Aesthetics of Everyday Life [M]. Columbia University Press, 2005. 